\title{
A KÖRNYEZETI MIGRÁCIÓ OKAI
}

\section{(Explaining Environmental Migration)}

\section{VÁG ANDRÁS}

\begin{abstract}
Kulcsszavak:
népességföldrajz népesség területi elhelyezkedése területi mobilitás migráció területi különbségei környezetromlás természeti katasztrófa konfliktus

A tanulmány a területi mobilitás egyik új formájával, a környezeti migrációval foglalkozik. Az irás módszertani megközelitése alapvetően elméleti. Rövid összefoglalást nyújt a téma kutatásának eddigi eredményeiröl, ismerteti a magyarázatok elméleti kiindulópontjait, végül felvázol egy általános környezeti migrációs modellt.
\end{abstract}

\section{Bevezetés}

A környezeti menekültek problematikája 2005 táján váltott ki először komoly érdeklődést, inkább a környezetromlás, mint a népességföldrajz kutatóinak körében. Ekkortájt figyeltek fel először arra a jelenségre, hogy a környezet állapota számos helyen - részben a klímaváltozás, részben a közvetlen emberi beavatkozások miatt - oly mértékben leromlott, hogy az ott élő embereknek önfenntartásuk érdekében el kellett hagyniuk lakhelyeiket. A médiaérdeklődést erősítette a klímaforgatókönyvek megjelenése is. Ebben az időben kezdett a kényszerü migráció kutatása - amely eddig elsősorban a politikai és etnikai konfliktusok következményeit elemezte a környezeti migráció felé fordulni. A washingtoni Worldwatch Institute évente kiadott „A világ helyzete” címü sorozatában a 2005. évi kötet külön alfejezetben foglalkozik a környezeti menekültekkel (Worldwatch Institute 2005). Mára a környezeti migráció kutatása azon interdiszciplináris témák közé tartozik, amely számos szaktudomány, így a környezet-tudomány, népességföldrajz, a közgazdaságtan, a szociológia és az agrárgazdaság módszereiből és eredményeiből is merít.

A „környezetromlás” fogalma egyrészt az emberi tevékenység nemkívánatos következményeit (erdőirtás, szennyezés, ipari létesítmények miatti természetromlás, stb.), másrészt a klímaváltozás jelenlegi és várható hatásait (hőhullámok, vízhiány, elsivatagosodás stb.), harmadrészt pedig az erőforrások egy részének kimerülését (talaj termőképességének csökkenése stb.) jelzi. 


\section{Hol tart a környezeti migráció kutatása?}

\section{A környezeti migráció meghatározásának rövid története}

A „környezeti menekült” kifejezés elöször Essam El-Hinnawinak az ENSZ Környezeti Programja keretében kiadott, 1985-ös könyvében bukkan fel. Definíciója szerint ,az a személy, akinek ideiglenesen vagy véglegesen el kellett hagynia életterét egy lehetséges környezeti veszély vagy az életfenntartó ökoszisztémák megzavarása miatt”. El-Hinnawi ezeket három kategóriába sorolja: (1) ideiglenes elköltözök valamely környezeti stressz következtében, mint például földrengés vagy ciklon; (2) végleges elköltözők az élőhely végleges megváltozása következtében, mint például új duzzasztógát építése; és (3) végleges elköltözők annak következtében, hogy eredeti élőhelyük már nem biztosítja alapvető szükségleteiket (El-Hinnawi 1985).

Lee Shin-wha 1994-ben a környezeti menekülteket azokkal a személyekkel azonosította, akiknek puszta életben maradásukhoz nincs más választásuk, mint hogy elhagyják addigi otthonukat, akár azért, mert ott természeti vagy emberi eredetủ ökológiai katasztrófa és környezetváltozás következett be, akár azért, mert országon belül áttelepítik vagy külföldre űzik őket kárt okozó nagy beruházások, a kormány környezetromboló intézkedései és a helyreállítás során bizonyos csoportok ellen alkalmazott diszkrimináció miatt (Lee S. 1994).

Norman Myers szerint környezeti menekült az, akinek létbiztonsága hazájában azért szűnik meg, mert ott aszály, talajerózió, sivatagosodás és egyéb környezeti problémák lépnek fel, együtt a népesedési nyomás és a mély nyomor hatásaival. Ezek az emberek kétségbeesésükben nem ismernek egyéb alternatívát, mint hogy menedéket máshol keressenek, még ha az veszélyes is. Nem mindegyikük távozik hazájából, sokan válnak 'belső lakhelyelhagyóvá'. Saját eredeti közegükből azonban mind kikerülnek, kevés reménnyel a belátható idejü visszatérésre. Myers azt állítja, hogy az 1990-es évtized közepén legalább 25 millió környezeti menekült volt, vagyis ez a hivatalos nyilvántartáson kívüli tömeg meghaladta a nyilvántartott menekültek 22 milliós létszámát. Úgy gondolja továbbá, hogy számuk 2010-re akár megkétszereződhet, és talán még gyorsabban nő a globális felmelegedés miatt. A kényszerű elvándorlás kockázatával előbb-utóbb nem kevesebb, mint 200 millió embernek kell szembenéznie. Myers meg van győződve arról, hogy a környezet változása és az ezzel összefüggő természetes vagy emberi tevékenység által kiváltott katasztrófák milliókat kényszerítenek otthonuk elhagyására. Nem feltétlenül közvetlen módon, hanem úgy, hogy a környezeti problémák egyrészt az ökológiailag törékeny térségekben élesítik a versenyt a termőföldért, másrészt elszegényedést okoz, ami viszont a jogtalan földhasználat elharapódzását váltja ki. Mindezek politikai és etnikai konfliktusokat eredményeznek, amelyek később könnyen erőszakba és háborúba torkollnak - ami aztán a menekülés közvetlen oka lesz (Myers 1994).

Lonergan szerint „,bizonyos esetekben ... megkísérelhetjük, hogy a környezet hatását a népességmozgás egyik fontos okaként azonosítsuk, és ennek alapján olyan 
beavatkozást tervezzünk, hogy az ilyen esetek negatív következményei a lehető legkisebbek legyenek" (Lonergan 1998, 6). Nyilvánvaló, hogy a romló környezet és a kimerülő erőforrások befolyásolhatják a népesség mozgását, gyakran átszürve a nyomor és az egyenlőtlenség kontextusán. A másik irányban a népességmozgás kiváltképp, ha tömeges - néha károsan hat a fogadó terület természeti környezetére. Hatékony stratégia kialakításához elengedhetetlen, hogy nagyobb figyelmet fordítsunk a környezet, a népesség és a szegénység közötti összefüggésekre, felmérjük, hogy a környezetváltozásra mely csoportok a legérzékenyebbek, és azonosítsuk a várhatóan legveszélyeztetettebb és legbizonytalanabb régiókat, amelyek különösen nagy migrációs és menekültnyomásnak lesznek kitéve (Lonergan 1998).

Künçek álláspontja szerint „,a környezeti menekültek problémája ma a következő okok sorozatának következményeként jelenik meg: földtelenség, erdőpusztulás, sivatagosodás, talajerózió, vízhiány és aszály, az öntözött földek szikesedése, a mezőgazdaság káros környezeti hatásai, a biológiai sokféleség csökkenése, éghajlatváltozás, szélsőséges időjárás eseményei, túlnépesedés, betegségek és alultápláltság, mérgező vegyszerek, egészségkárosító hulladékok, az ökoszisztémát sújtó szennyezés és radioaktív sugárzás." (Künçek 1998, 7).

Richard Black véleménye szerint kizárólag környezeti jellegü menekültek nem léteznek. A környezeti tényezők szerepet játszanak ugyan a kényszerủ migrációban, de mindig szorosan kötődnek más politikai és gazdasági tényezőkhöz. Ezért, ha elkülönítve fókuszálunk rájuk, nem érthetjük meg a népesség helyváltoztatásának sajátos helyzeteit. Az apokaliptikus neo-malthusi víziók Black szerint kétséges feltételezéseken alapulnak, ezért elvetendők, különösen akkor, ha az a következtetésük, hogy a menekültek (és általában a lakhelyet változtatók) fenyegetik a társadalom biztonságát. Black nem lát bizonyítékot arra, hogy a környezetváltozás közvetlenül tömeges menekültáradathoz vezetne, kiváltképp a fejlett országok felé. A környezeti menekültek problémájának hangsúlyozása szerinte eltereli a figyelmet a fejlesztés és a konfliktusfeloldás központibb témáiról (Black 1998).

Castles egy 2001-es tanulmányában kifejti, hogy a 'környezeti menekült' kifejezés túlegyszerüsített, egyoldalú és félrevezető. Egyetlen okot feltételez, ami a gyakorlatban rendkívül ritka (Castles 2001). Sőt, a nemzetközi jog szempontjából is problematikus, amelyben a 'menekült' fogalomnak pontosan körülhatárolt jelentése van. A menekültek státuszára vonatkozó, 1951-es ENSZ-konvenció szerint menekült az a személy, aki saját országába nem térhet vissza, mert ott 'faji, vallási, nemzetiségi, társadalmi csoportbeli hovatartozása vagy politikai véleménye miatt üldöztetéstől kell tartania'. Akit valamilyen környezeti probléma üz el otthonából, arra a fenti definíció nyilvánvalóan nem érvényes. Pusztán a környezetromlásra hivatkozva senki sem kap menedékjogot. A 'környezeti menekült' kifejezésnek csak abban a szük értelemben lehet jogi jelentése, hogy valakinek emigrálnia kellett, mert az elnyomó erők egy célcsoportjukkal szemben harci eszközként alkalmazták a környezet szándékos rombolását, mint pl. növényirtást vagy vízszennyezést (ahogy például az USA hadserege tette a vietnami Orange-hadmüvelet során). Az érintett 
csoportok menekültstátusza ilyenkor magán az üldöztetésen alapul, és nem annak formáján, ami a 'környezeti menekült' szókapcsolatot fölöslegessé teszi.

A definíció kérdését azonban ilyen könnyen mégse kerülhetjük meg, mivel az országba érkezőkkel szembeni kormánypolitikát és a nemzetközi ügynökségek magatartását erősen befolyásolja, hogy kit tekintenek menekültnek, kit más típusú kényszerü lakhelyelhagyónak, és kit önszántából jött emigránsnak. A definíciók általában tükrözik a hatalmon lévők viszonyát a definíció tárgyához, és ez nincs másképp a jelen esetben sem (Castles-Miller 1998).

Az FMO (Forced Migration Online) (www.forcedmigration.org) szerint a kényszerü migráció ,általános kifejezés olyan emberek mozgására, akik elmenekülnek országukból, vagy valamilyen konfliktus miatt az országukon belül kényszerülnek lakhelyet változtatni, illetve akiket elüz otthonukból egy természeti, vegyipari vagy nukleáris katasztrófa, éhínség vagy szervezett környezetváltoztatási projekt”. Az FMO a kényszerü migráció három különálló, bár néha egyidejü és egymással összefüggő típusára fordít megkülönböztetett figyelmet, okok szerint kategorizálva azokat, amelyeket 1) konfliktusok, 2) nagy beruházások és 3) katasztrófák váltanak ki.

Konfliktus által kiváltott lakhelyváltozás fogalma: Az ide tartozó emigránsok egy vagy több okból elhagyni kényszerülnek otthonukat, ahol az állami hatóságok nem tudják, vagy nem akarják őket megvédeni. Az ok lehet fegyveres konfliktus, beleértve a polgárháborút, általánossá vált erőszakos cselekményeket, valamint nemzetiség, rassz, vallás, politikai meggyőződés vagy speciális társadalmi csoporthoz való tartozás miatti üldöztetést. Az ilyen okból elvándorlók nagy százaléka az országhatáron túl keres menedéket. Néhányan a nemzetközi jog alapján nyíltan menekültstátuszt kérnek, míg mások ebben nem bízva, félelmükben attól, hogy visszatoloncolják őket eredeti hazájukba, inkább megpróbálnak a hatóság látóköréből kimaradni. A közelmúlt idevágó konfliktusai nagyrészt belső jellegüek voltak, nemzetiség, etnikum vagy vallás alapján elkülönült csoportok között folytak. Ebben az időszakban a menekültek száma jelentősen megnőtt, mivel ellenségeik elüzése egyre inkább beépült a szemben álló felek stratégiájába.

Nagy beruházásokkal kiváltott migráció definíciója: Gyakran az embereknek azért kell lakóhelyükről elköltözniük, mert azt nagy beruházásokra jelölik ki. Erre példák a nagyméretü infrastrukturális projektek, mint duzzasztógát, út, kikötő, repülőtér, egy városrész szanálása, bánya nyitása, természetvédelmi terület létesítése vagy más bioszféra-védelmi program. Az érintett lakosok ilyenkor általában az ország határain belül maradnak. Bár néhányukat hatósági segédlettel máshova telepítik, a többség igen gyakran nem részesül megfelelő kárpótlásban. A migráció okainak ez a típusa kétségtelenül gyakoribb, mint a fegyveres konfliktus, mégis gyakran kevésbé figyelnek fel rá, és az érintetteket kevéssé támogatják. Az FMO becslése szerint az 1990-es évtizedben a világon 90-100 millió ember volt kénytelen elhagyni otthonát infrastruktúra-fejlesztés miatt.

Katasztrófák által kiváltott lakhelyváltoztatás fogalma: Ebben a kategóriában olyan emberek szerepelnek, akiknek kényszerü lakhelyváltoztatását természeti csapás (pl. árvíz, vulkánkitörés, földcsuszamlás, földrengés), a környezet minőségének rom- 
lása (pl. erdőpusztulás, termőföld elsivatagosodása), illetve emberi eredetű katasztrófa (pl. ipari baleset, radioaktivitás) idézte elö. A fenti okok természetesen átfedhetik egymást; például egy árvíz vagy földcsuszamlás hatását esetleg tovább rontja, hogy a helyi erdőket előzőleg letarolták, vagy bizonyos mezőgazdasági eljárások következtében a talaj fellazult. A katasztrófa miatt otthonukat vesztettek globális számának és e szám változási trendjének becslése még vitatottabb és problematikusabb, mint a másik két kategóriába tartozóké. Annyi biztos, hogy évente több millióan vannak.

Az IOM a környezetromlás által kiváltott migrációra a következő munkadefiníciót adja: ,,a környezeti migránsok olyan személyek vagy csoportok, akiket az életükre vagy életfeltételeikre károsan ható, hirtelen vagy fokozatos környezetváltozás lakhelyük elhagyására kényszerít, illetve emiatt egy időre vagy végleg kénytelenek saját elhatározásukból más helyre távozni hazájukon belül vagy kívül” (IOM 2007).

\section{Mit tudunk a környezeti migrációról?}

Bár a környezeti migrációról az utóbbi évtizedben sok szó esett - eltekintve néhány fejlődő országra vonatkozó esettanulmánytól és történelmi összefüggésekböl levont következtetéstől -, hiányzik a mai világunkra érvényes összehasonlító kutatás. Egyedi helyszínekröl, egyedi eseményekről vannak becslések, de ezek a jelenség összességének ismeretéhez nem elegendőek. Nem ismertek a környezeti migrációs döntések motivációs mechanizmusainak részletei sem.

A migráció nincs determinisztikus kapcsolatban a környezetromlással. Ahogy Lonergan rámutat, a migrációt mint „helyi, országos és nemzetközi szinten működő, összetett gazdasági, társadalmi, kulturális, népesedési és politikai folyamatok hasonlóan összetett és igen változatos manifesztációját" szokás jellemezni. A tényezők között szerepel az egyszerünek szintén nem mondható környezet is, amely részét képezi a társadalom szociális, gazdasági, politikai és intézményi struktúrájának, így nem hagyható figyelmen kívül. A környezetromlást épp az összefüggések komplexitása miatt nemcsak helytelen, hanem egyenesen lehetetlen determinisztikus és lineáris kapcsolatba hozni a migrációval (Lonergan 1998).

A helyi migrációt részben globális folyamatok határozzák meg. A globalizáció negatív következményei - a pozitív értékelések csökkenésével párhuzamosan - egyre markánsabban jelentkeznek. Ahogy a viszonylag szegény vidékiek tömege a váro-sokba áramlik, társadalmi feszültség alakul ki: városi gettók állnak szemben a gazdagok gondosan örzött lakóparkjaival. Részben a globalizáció hatására a mezőgazdaság alapvetően piacorientálttá válik. A folyamatos környezetromlás megváltoztatja a gazdálkodás természeti feltételeit, amihez - a nem megfelelő szakpolitikák miatt - csak a kellő tőkével rendelkezők, főleg a szervezett nagyüzemek képesek alkalmazkodni. A fejlődő országok jelentős részében megfigyelhető az önfenntartó mezőgazdaság visszaszorulása. A falusi környezetet az intenzívebb mezőgazdaság és a városok terjeszkedése negatívan befolyásolhatja, elvész számos védett terület és nagy természeti értékủ termőföld és főként - ugyan országonként eltérő léptékben - csökken a vidéki 
munkahelyek száma. Mindez azt mutatja, hogy a globális történések folyamatosan meghatározzák a migráció taszító tényezőit, beleértve ebbe a környezeti migrációt is.

A környezetei feltételek szinte mindenhol romlanak. A környezeti feltételek mind globális, mind regionális szinten egyfolytában rosszabbá válnak. Ezzel párhuzamosan tanúi lehetünk jelentős szervezeti, müszaki és jogi előrelépésnek, intenzív kárenyhítési és megelőzési tevékenységnek, valamint - sajnos föleg csak a fejlett országokban - fontos környezetromlás elleni intézkedésnek is. Ennek ellenére az alapvető tendencia a környezeti feltételek romlása, ami hosszú távon is a migráció egyik motivációja lesz.

A környezeti tényezö összefonódik a társadalommal és a gazdasággal. A környezetromlás és a klímaváltozás - csakúgy mint következményeik (mint például a környezeti migráció) - mélyen be vannak épülve a társadalmi-gazdasági folyamatok szövetébe. A környezeti tényező nem tekinthető elkülönült jelenségnek, mivel dinamikus kölcsönhatásban van a gazdasággal, a szakpolitikai intézkedésekkel és a társadalommal, nemzeti és nemzetközi szinten egyaránt. Különösen fontos szerepe van a szegénységnek és számos esetben a környezeti egyenlőtlenségnek.

A népsürüség növekedése a természeti csapások hatásait súlyosbitja. A természeti csapások - mint például árvíz, aszály és földrengés - egyre több embert űznek el lakóhelyükről, nem szükségképp azért, mert az ilyen események súlyosabbak lesznek, hanem mert a népsürüség növekedésével egyre több embert érintenek, kiváltképp a csapásoknak kitett régiókban. Ebből a szempontból elsősorban a rohamosan növekvő lélekszámú települések a legveszélyeztetettebbek, amelyek ilyenkor migráció-forrássá válnak.

A környezeti migráció hasonlit a migráció más típusaihoz. A természeti csapásokból eredő migrációtól (kitelepítéstől, meneküléstől) eltekintve a környezeti migráció, több szempontból is, hasonlóságot mutat a migráció egyéb fajtáival, mint például a gazdasági migrációval. Ebben az összefüggésben a hasonlóság azt jelenti, hogy a környezeti szempontból leromlott területről elvándorlókat a „hagyományos” taszító és vonzó erök (pl. a nyomor otthon és a jobb lehetőségek máshol) ugyanúgy befolyásolják, mint a többi migránst.

A természeti katasztrófák gyakran tartós elvándorlással járnak együtt. A természeti katasztrófák után a helyreállítás (néha még a viszonylag gazdag területeken is, pl. a Katrina hurrikán után New Orleansban) évekig vagy évtizedekig tarthat. Vannak olyan helyek, amelyek egy természeti csapás (vagy éppen közvetlen emberi okokra visszavezethető ipari katasztrófa, pl. Csernobil) után végleg elnéptelenednek. Számos példa van arra is, hogy a menekültek letelepedtek új lakóhelyeiken, és már nem akarnak (vagy nem tudnak, pl. mert nincs pénzük újra felépíteni lerombolt otthonaikat) visszamenni korábbi, katasztrófa sújtotta lakóhelyükre.

A nagy beruházások miatt az eredeti lakosság kitelepitése legtöbbször végleges. A nagy beruházások miatt történt kitelepítések általában véglegesek, hiszen az ipari létesítmények elfoglalják az adott területeket, vagy a gátak (pl. a Három Szurdok Gát a Jangce folyón) építése miatt a felduzzasztott vagy eltérített folyók elöntik a korábbi lakóterületeket. 
A társadalmi-ökológiai rugalmasság szintje befolyásolja a migrációt. Minél többet tud egy kormányzat a környezetromlás hatásainak megelőzésére, és főként a már bekövetkezett káros következmények mérséklésére, a helyreállításra költeni, annál kisebb arányú (vagy volumenü) környezeti migráció valószínűsíthető. Ez az egyéni adaptáció szintjén is érvényesül. A tehetösebbek - amennyiben az adott területen maradnak - minden szempontból könnyebben alkalmazkodnak, mint a szegényebbek. Ez utóbbiak lehetőségeik korlátait gyakran „,szokatlan” magatartással igyekeznek tágítani, ilyen lehet például a nagyobb kockázatvállalás vagy a normák és jogszabályok megszegése (pl. illegális migráció). Nem kétséges azonban, hogy ahol akár a kormányzati szakpolitikák, akár a lakosság problémakezelési kultúrája támogatja a környezeti kihívásokra adott rugalmas válaszokat, ott a környezeti migráció szintje viszonylag alacsony.

A környezeti migráció támogatása az adaptációs politika része is lehet. Az adaptáció sajátságos formájának minősülnek azok az esetek, amikor az egyének, és igen gyakran a kormányzati politika is, lemondanak a sérült területeik helyreállításáról és helyette azok elhagyását választják. Különböző meggondolásokból ugyan, de számos kormányzat nem csak tudomásul veszi ezt a megoldást, hanem kifejezetten támogatja (pl. Törökország).

A különféle társadalmi csoportok a környezet változására különféle módon reagálnak. Ez a megállapítás egyrészt kézenfekvő, másrészt a környezeti változásokra társadalmi csoportonként adott reakciók részletei kevéssé ismertek, ezért ezek a jövőben bizonyára fontos kutatási kérdések kiindulópontjai lesznek. Megállapítható, hogy a dolog strukturálódik, és összetett kölcsönhatások alakítják az egyes környezetromlási típusok és társadalmi csoportok kapcsolatait, mind az országokon belül, mind országok közötti összehasonlításban.

A környezeti migráció az esetek egy részében konfliktusokkal jár együtt. Ha a migráció egyéni és társadalmi diszharmóniával, feszültséggel jár együtt, akkor a környezeti migrációra ez a megállapítás különösen érvényes. Vagy azért, mert a környezeti okok rárakódnak az egyébként is meglévő gazdaságiakra, vagy azért, mert a szükös természeti erőforrásokért folyó küzdelem vezet ellentétekhez. Csoportok közötti konfliktusnak tekinthető az is, amikor a hatalmon lévő elit az ország erőforrásait, legyenek azok akár a természet kincsei, akár külföldi támogatások vagy egyéb pénzforrások, nem a környezeti migráció okainak mérséklésére, hanem saját jólétének növelésére fordítja.

A környezetromlás közvetlen és közvetett módon egyaránt kiválthat migrációt. A szakirodalomban a „közvetlen” és a „közvetett” jelző használata nem szisztematikus, sok ok-okozati magyarázatban nélkülözi a következetességet. Amit közvetlen hatásnak hívunk, az általában rövid távú és jól megfigyelhető (pl. környezeti csapás vagy ipari baleset, mint Csernobil vagy Bhopal), míg amit közvetettnek neveznek, az vagy lassan alakul ki, vagy a hatásmechanizmusok nem egyértelmüek, például a multikauzalitás miatt (ilyen volt Ruanda esete, ahol a migrációt közvetlenül kiváltó konfliktus gyökerei között a környezetromlás is szerepelt). Mindazonáltal a legtöbb esetben a két típus együtt van jelen. 
Lassú környezetromlásnál a gazdasági és a környezeti migráció egybeolvad. A környezetváltozás hatásait a népességmozgás sok formájában igen nehéz elkülöníteni a többi, legtöbbször gazdasági vagy túlnépesedési októl, különösen olyankor, amikor a migráció „önkéntesebbnek” tünik. Lassú környezetromlás esetében, makroszinten a „hagyományos” és a környezeti migráció morfológiája nem különbözik lényegesen, mikroszinten pedig az érintettek nem mindig észlelik a környezet állapotának romlását, hanem elsősorban a gazdasági, életszínvonal-különbségbeli okokat látják.

A helyi környezeti hatások nagyobb migrációs taszítóeröt jelentenek, mint a klímaváltozás következményei. Az utóbbi években úgy tünik, hogy a helyi környezeti hatások (pl. a közvetlen emberi eredetü katasztrófák, a nagyterületü ipari létesítmények, a mezőgazdasági termelés működési hiányosságai, az áradásokhoz való rossz alkalmazkodás és a helyi környezeti konfliktusok) sokkal több embert üztek el otthonukból, mint az éghajlat lassú, globális változásából fakadó környezetromlás (pl. elsivatagosodás, tengerszint emelkedés). Feltételezhetően ez a tendencia érvényben marad, bár a különbség - az egyre intenzívebb felmelegedéssel - a kétféle okozat között egyre inkább csökken, sőt hosszabb távon meg is fordul majd.

A környezetromlás jelentösége folyamatosan növekszik a migrációs taszitás tényezői között. Ahogy a környezeti feltételek rosszabbodnak és a globális klímaváltozás következményei egyre nyilvánvalóbbak lesznek, úgy nő a környezetromlás súlya a migrációs taszítóerők között. Más szóval, ha a migráció „hagyományos” taszítási tényezőihez hozzávesszük még a környezetet is, akkor - mint magyarázó elem - ez utóbbi feltételezhetően egyre fontosabbá válik. Ezt minden kontinens környezeti állapotának értékelése és esettanulmány alátámasztja. Kivételek természetesen akadnak, de a figyelem egyre inkább a környezetromlásra, mint taszítóerőre irányul.

Nincs egyértelmü összefüggés a társadalmi sérülékenység és a környezeti migráció között. Miként azt a társadalmi sérülékenység vizsgálatok hangsúlyozzák, a sérülékeny csoportok a szegények, az etnikai kisebbségek, a nők, a gyerekek és az idősek. Kérdéses azonban, hogy a sérülékenység növekedése minden esetben együtt jár-e a környezeti migráció növekedésével. Feltételezhetö, hogy a környezeti migráció - föként a nemzetközi környezeti migráció - terheit, nehézségeit a legsérülékenyebb csoportok nem képesek vállalni (pl. a legsérülékenyebb bangladeshiek, szub-szaharai afrikaiak vagy balkáni romák). A kapcsolat a két jelenség között tehát nem tekinthető lineárisnak. Ez a sajátosság a fejletlen országokban ugyanúgy megfigyelhető, mint a fejlett Európában. Elég akár a 2003-as európai hőhullám 20 ezer fő feletti idős halottjára vagy a Szub-Szaharai térség legelesettebb időseire és gyerekeire gondolni.

A környezeti migráció növekedésének legföbb oka a rosszul müködö intézményrendszer. Ha egy társadalom lehetséges válaszait, adaptációs mozgástereit tekintjük, akkor a környezeti migráció növekedéséért elsősorban a rosszul müködő intézményrendszer a felelős, mivel elmulasztotta a szükséges helyreállító, segítő és megelőző lépések megtételét. A legtöbb helyen a környezetpolitika kialakítói nem vették tudomásul kellő hangsúllyal a gazdasági növekedés környezeti hatásait és a szennyezés vagy az erőforrások leromlása nem kapott megfelelő figyelmet. Ha egy kormány mégis felállított környezetvédelmi szabályokat, azoknak sem a tervezésük, 
sem a megvalósításuk nem volt elég hatékony. Miközben körültekintő környezeti szabványokat és szigorú szabályozó mechanizmusokat vezettek be, addig igen gyakran nem törődtek az ellenőrzéssel és a betartatással. A környezet újfajta kezeléséhez hiányzott az együttmüködés az intézkedések hatékonyan végrehajtása érdekében. Tipikus területe ennek a folyamatnak Ázsia.

\section{Egy környezeti migrációs elmélet kiindulási pontjai}

A környezeti migráció különféle formái nem érthetök meg egyetlen megközelítési mód vagy egyetlen tudományág nézőpontjából. A tárgyra azáltal tudunk szélesebben rátekinteni, hogy értékelésünkbe több tudományág és több koncepció elemeit építjük be. Egy általános környezeti migrációs elmélet megfogalmazásához egyszerre háromféle irányból célszerủ közelíteni: 1) a migrációs elméletek, 2) a társadalmi-gazdaságikörnyezeti változások modelljei és 3) a konfliktusmodellek felől. A migrációs elméletek azért szükségesek, mert a környezeti migráció sok szempontból hasonlít, illetve egybefolyik a migráció többi típusával. A társadalmi-gazdasági-környezeti változások modelljei a három szféra kölcsönhatásait foglalják össze, míg a konfliktusmodellek azért fontosak, mert a migrációs folyamat - különösen annak kezdet és végpontja igen gyakran egyéni és csoport-konfliktusokkal terhes.

\section{Migrációs elméletek}

A migráció szakirodalma csak az utóbbi évtizedekben kezdett behatóan foglalkozni a nemzetközi migrációval, előtte a kutatások jórészt a belső mozgásokat írták le. Jelenleg a nemzetközi migráció kutatásának gyorsan terjedő szakaszában vagyunk, melynek fontos része a különféle elméletek felhasználása. A nemzetközi migráció szociológiai elméletei közül Lee tárgyalta a jelenséget először az azóta is legnépszerübb fogalmakkal, a taszítással és a vonzással (Lee E.1966). Számos szerző hivatkozik Ravensteinre (1885) is, akihez a taszítás-vonzás elméletének korai megjelenését kapcsolják. A migrációs elméletek részletes áttekintése Hárs (1992), Massey et al. (1993), Greenwood (1992), Suhrke (1993), Zlotnik (1998) müveiben olvasható.

\section{A társadalmi-gazdasági-környezeti kölcsönhatások modelljei}

A társadalmi-gazdasági-környezeti változások modelljei (többségükben oksági vagy strukturális modellek) kiemelik a legfontosabb elemeket, és azokat kölcsönhatásaikkal együtt - általában vizuálisan - blokkdiagrammokban ábrázolják. A hatásirányokat a struktúrában nyilak jelzik, melyek a verbális magyarázat során oksági értelmezést kapnak.

Az egyik leggyakrabban idézett és különféle verziókban feldolgozott modell Barker „,a klímaváltozás oksági kerete” nevü modellje. A modell négy fő területet 
kapcsol össze: 1) a társadalmi-gazdasági fejlődési pályákat; 2) a szennyezőanyag kibocsátást és koncentrációt; 3) a klímaváltozást és 4) ezek természeti és társadalmi hatásait (Barker 2001). A körkörös ábrázolás a bonyolult összefüggésrendszer dinamikus jellegét sugallja: bárhol is történik beavatkozás, az az egész rendszerre kihat (1. ábra).

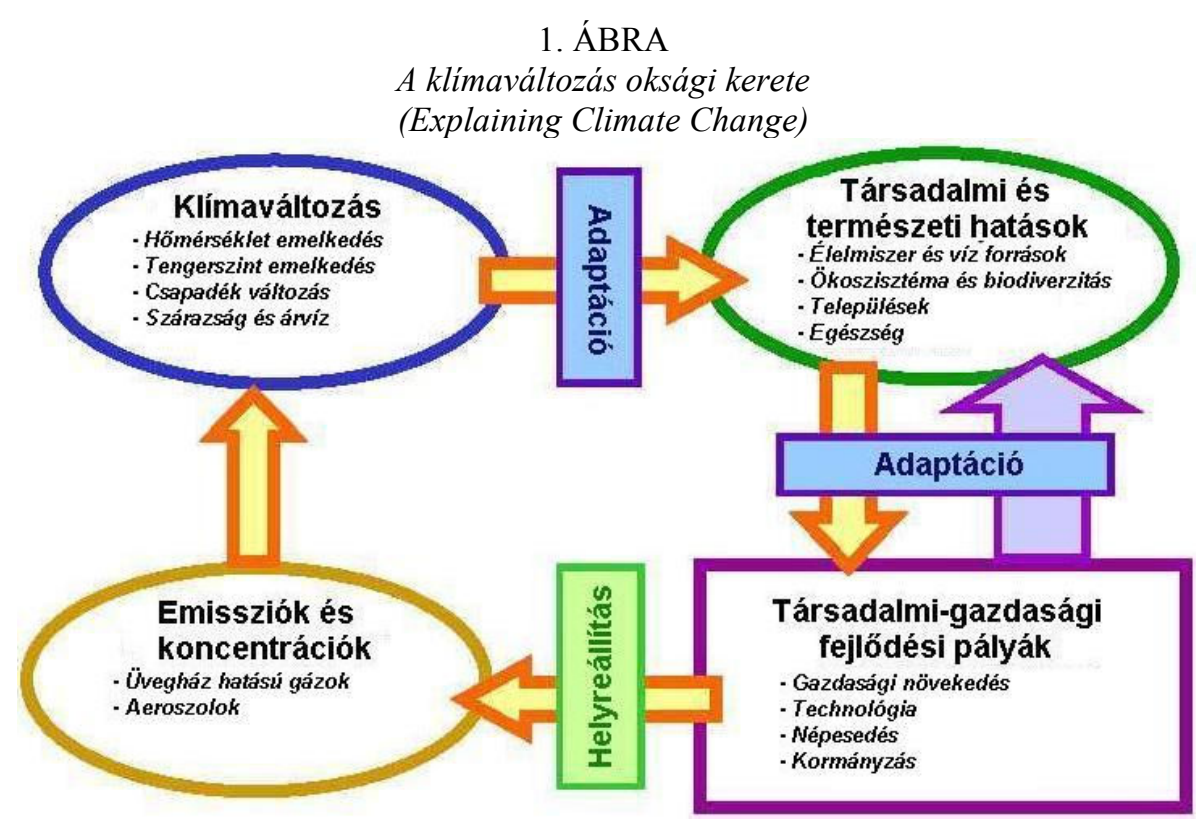

Forrás: Barker (2001, 9).

Említést érdemel még Roson ,a klímaváltozás hatásai és a CGE világmodellje” és Kavanagh-Lonergan „népességkiszorítás, környezetromlás, biztonság” modellje. Roson a klímaváltozás gazdasági és egyéb hatásainak modellezésére egyrészt ,integrált értékelési modellekkel" vagy hatásmodellekkel elemzi a hatásokat, másrészt azokat egy „számszerüsített egyensúlyi modellel” kapcsolja össze. Megközelítésének számos előnye mellett kiemelkedő jelentőségü, hogy az egyes környezeti hatásokat - az egészségügytől kezdve a földhasználaton át az energiáig - és „,megrázkódtatásokat” külön al-modellekben is elemzi (Roson 2003). A Kavanagh-Lonergan modell meglehetősen összetett, sok szempontot vesz figyelembe. A modell szisztematikusan áttekinti a jelenségkör ,alapvető” és „,kapcsolódó” faktorait, a „közvetlenül kapcsolódó okokat”, valamint a „másodlagos” és „hosszabb távú” hatásokat. Szociológiai és politikai szempontból figyelemreméltó, hogy a modellben megjelenik a ,hatalomdelegálás" (empowerment) mint közreható tényező (Kavanagh-Lonergan 1992). 


\section{Konfliktusmodellek}

Ahogy Ruanda korábbi védelmi minisztere kifejezte országa ismert tragikus eseményeiről szólva: „a nagy jelentőségü környezeti tényezők a természeti erőforrásokkal függnek össze, mégpedig a népesedési nyomással, az egy családra jutó mezőgazdasági terület csökkenésével, .... talaj leromlásával és a tüzifahiánnyal" (Gasana 2000 - idézi Lind 2001). Tudományos módszerekkel ezt az egyértelműen megfogalmazott diagnózist Homer-Dixon (2004), Schwartz (2002), Brauch (2005), valamint Schubert és szerzötársai (2008) magyarázzák.

Arra, hogy a környezeti kérdések biztonsági kérdésekké válnak, néhány elemző például Myers-Kent (1995) és Homer-Dixon (2004) - már figyelmeztetett. HomerDixon szerint már „küszöbén vagyunk” egy olyan korszaknak, amelyben a hagyományos biztonsági problémák, mint a fegyveres konfliktusok, gyakran vagy akár föleg a környezet változása miatt alakulnak ki (Homer-Dixon 2004). Az ilyen állítások fontos szerepet kapnak a 'konfliktuskutatás' és a 'politikai demográfia' fejlödésben lévő kutatási részterületein. A népesség kikényszerített helyváltoztatását egyre gyakrabban az államok közti konfliktusok és a fegyveres harc egyik lényeges kiváltó okának tekintik. A közelmúlt számos nemzetközi katonai intervencióját részben a menekültáradat megelőzésének szándéka motiválta.

Mi tehát a bizonyíték környezeti konfliktusok okozta elvándorlásokra? Black áttekintette az 1990-es évek 11 legnagyobb olyan konfliktusát, amely menekülthullámmal járt, és kimutatta, hogy többük távolról sem forrásszegény körzetben zajlott, hanem épp az értékes nyersanyagok elosztása körül tört ki. Ilyen nyersanyag volt mindenekelött az olaj Irakban, Szudánban és Azerbajdzsánban. Máshol viszont - pl. Szomália és Sierra Leone - a környezeti tényezők szerepet játszottak ugyan, de sokkal kisebbet, mint az etnikai ellentétek és a politikai hatalomért folyó harc (Black 1998).

Az 1980 és 1992 közötti konfliktusok még átfogóbb vizsgálata Hauge és Ellingsen (1998) nevéhez füződik. A szerzők pozitív korrelációt találtak egyrészt a föld minőségromlása, az erdőpusztulás és a vízhiány, másrészt a polgárháborúk között. A korreláció számszerü mértéke azonban igen csekély volt, a konfliktus kitörésének valószínüségét mindössze 1\%-kal növelte. Sokkal jelentösebb tényezönek bizonyult például az életszínvonal, az államhatalom jellege és az aktuális vagy előzetes politikai instabilitás. Más áttekintések (Goldstone 2001) ugyanerre az eredményre jutottak: a hosszú távú környezeti változás elemeit önmagukban nem lehet az erőszak kiváltó okainak tekinteni.

Mindez nem azt jelenti, hogy a környezeti tényezök nem okoznak konfliktust, hanem inkább azt, hogy az okozott konfliktus rendszerint nem erőszakos. Többek között azért sem, mert az olyan viták, mint amelyek, például egy határfolyó vízhasználati jogára vonatkoznak, nem oldhatók meg katonai erő alkalmazásával. Ahogy Goldstone rámutat, az ilyen konfliktusok a környezet és a népesedés új típusú biztonsági kérdéseit jelentik, amiket erőszak nélkül, azaz tárgyalással és megegyezéssel kell feloldani. Példaként említi a vízjogi tárgyalásokat India és Bangladesh, Izrael és Jordánia vagy Magyarország és Szlovákia között (Goldstone 2001). Ezzel 
szemben a rövid távon ható katasztrófák - mint a hurrikánok, árvizek, földrengések és ipari balesetek - sokkal nagyobb politikai zavarral járhatnak, nem annyira önmagukban, hanem az érintett kormány reakciói miatt.

A társadalmi-gazdasági-környezeti modellekhez hasonlóan környezeti konfliktus modelleket is publikáltak. Ilyen például Homer-Dixon „környezeti szükösségeröszak” modellje, Schwartz ,a környezeti stressztől a konfliktushoz vezető utak” modellje és Brauch ,a klímaváltozás hatásai és a konfliktusok ötszögei” nevü koncepciója.

Homer-Dixon „környezeti szükösség-erőszak” modellje a következő gondolatmenetet tartalmazza. „Kínálat-indukálta szükösség” a kínálat csökkenésével jön létre, míg a „kereslet indukálta szükösség” értelemszerüen a kereslet növekedésével jön létre. A „strukturális szükösség” a különféle csoportoknak az erőforrásokhoz való relatív hozzáférésében beálló változásával jön létre. A szűkösségben valamilyen formában érintettek, akik általában gazdaságilag és ökológiailag már egyébként is marginális helyzetben vannak, gyakran vagy maguktól elvándorolnak vagy elüzik őket más vidéki területekre vagy a városokba. Az elvándorlók új lakhelyeiken elsősorban etnikumok közötti - csoportidentitás-konfliktusokat gerjesztenek, amit tovább súlyosbít a helyi gazdaságban is jelenlévő hanyatlás. Mindez közvetlenül vezet a hatalommal szembeni felkelésekhez vagy csoportközi összeütközésekhez. A migráció, a termelékenység csökkenése és az elitcsoportok járadékvadász magatartásának hatására további társadalmi szegmentálódás alakul ki, és mélyülnek a csoportidentitáson alapuló konfliktusok is. Ezek a folyamatok általában gyengítik a nemzeti intézményeket, emiatt pedig csökken a központi ellenörzés, például az etnikai versengés fölött. A kínálat indukálta, a kereslet indukálta és a strukturális szükösség külön-külön és egymással összefüggésben is hatnak, így fokozzák a környezeti szükösséget (pl. helyi és a regionális termőföld-, víz-, erdő- és halállományszükösséget). A növekvő szükösségek hatására - mind a helyi közösségekben, mind a nagyobb regionális vagy nemzeti gazdaságok szintjén - csökken a gazdasági termelékenység (Homer-Dixon 2004).

Schwartz ,a környezeti stressztől a konfliktushoz vezető utak” modelljében háromféle erőszakos konfliktus jelenik meg: 1) az állam elleni lázadás, 2) az identitáskonfliktusok és 3) a városi eröszak. Mindezek nem közvetlenül a környezeti stresszből származnak, hanem különféle társadalmi, gazdasági és politikai hatáson és elágazáson keresztül. A modellnek gyenge pontja, hogy a környezeti migrációt csak a konfliktusok egyik okaként ábrázolja, és nem szerepelteti a környezeti okokból eredeztethetö konfliktusokat a migráció egyik magyarázataként (Schwartz 2002).

Brauch ,a klímaváltozás hatásai és a konfliktusok ötszögei” címü modellje a környezeti konfliktusokkal foglalkozó szakirodalom gyakran idézett ábrázolása. A szerző a modellben különbséget tesz nemzeti és nemzetközi „gazdasági és társadalmi körülmények" között, ami a többi koncepcióhoz képest jelentős előrelépés. Brauch modellje részletekbe menően mutatja a környezeti migráció és a konfliktusok kölcsönhatásait. A többi modellel összehasonlítva nagyobb hangsúlyt helyezett a modellben a konfliktus-típusokra és kevesebbet a migrációt kiváltó környezeti hatásokra (Brauch 2005). 


\section{Egy általános környezeti migrációs modell}

A témával foglalkozó szerzők egyetértenek abban, hogy az esetek többségében a fokozatos környezetromlás, a természeti szélsőségek és katasztrófák, a nagyléptékü beruházások és környezeti eredetű konfliktusok ösztönzik a migrációt, míg a jól müködő intézmények, kormányzati struktúrák és szakpolitikák (kormányzati adaptáció), a gazdaság fejlettsége és az együttmüködő közösségek (helyi adaptáció) csökkentik. Az egyéni és társadalmi sérülékenység növekedése szintén növeli a migrációt, bár ezt az egyedi sajátosságok jelentősen befolyásolják.

\section{2. ÁBRA}

Egy általános környezeti migrációs modell (A Generalised Environmental Migration Model)

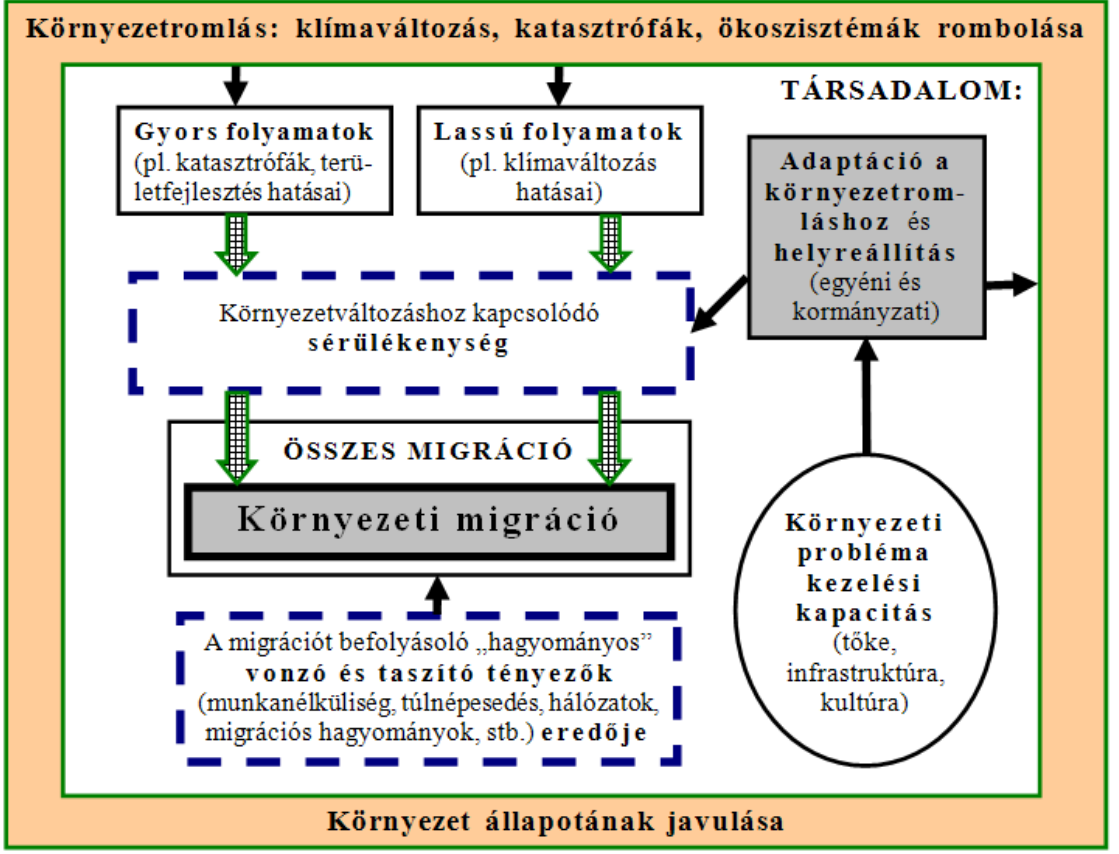

Forrás: Saját szerkesztés.

A 2. ábrán bemutatott modell a környezeti migráció általános-elméleti magyarázatát nyújtja. Kiinduló feltételezése a környezet állapotának folyamatos romlása és ezzel egyidejü helyreállítás (illetve a romlás hatásainak kiküszöbölése). A domináns folyamat az ökoszisztémák (élőlényközösségek) szolgáltatásainak gyors (pl. katasztrófák, nagy beruházások) vagy lassú (pl. klímaváltozás hatásai) romlása, csökkenése. A környezeti migráció az összes többi migrációba beágyazottan, attól elválaszthatatlanul jelenik meg. Ez alól kivételt jelentenek egyes, elsősorban hidro-meteorológiai katasztrófák, amikor az „összes többi” migráció sajátosságai nem vagy csak korlátozottan jelennek meg. 
A migrációs döntéseket - vagyis az érintettek álláspontját a „menni vagy maradni” kérdésben - a potenciális migránsok környezetváltozáshoz kapcsolódó sérülékenysége és a vonzó és taszító tényezők eredője alakítja. A sérülékenységet közvetlenül a környezetromlásra adott adaptációs válaszok és a kárenyhítés mértéke befolyásolja. Az adaptációnak és a környezet helyreállításának mértéke közvetlenül a helyi és országos kormányzati döntésektől függ, melynek gazdasági alapja, a modell logikája szerint, a környezeti problémakezelési kapacitás vagy tágabban fogalmazva az adott gazdaság fejlettsége.

A „vonzó és taszító tényezők” a modellben mindazokat a hatásokat tartalmazzák, amelyeket a migrációs elméletek ilyen címszó alatt felsorolnak, úgymint: szegénység, munkanélküliség, jobb életminőség utáni vágyakozás, túlnépesedés, migrációt megkönnyítő hálózatok stb. A modellben ezek összesített eredője szerepel, amely végül mint migrációs döntés jelenik meg.

\section{Összefoglalás}

A tanulmány a környezeti migrációval kapcsolatos legfontosabb ismereteket vázolja fel. Rövid összefoglalót ad a jelenség meghatározásának történetéről, melyben a hangsúly a 20. század végének és a 21 . század elejének eseményein van. Összegzi az elméleti megállapításokat, és tételesen felsorolja azokat a társadalmigazdasági összefonódásokat, amelyek a későbbi kutatások és szakpolitikák számára hasznosak lehetnek. A környezeti migráció kutatásának elméleti oldalához kapcsolódóan ismerteti azokat a koncepciókat, amelyek egy általános környezeti migrációs modell felépítéséhez szükségesek lehetnek. Végül bemutat egy vizuális ,általános környezeti migrációs modellt".

\section{Irodalom}

Barker, T. (2001) Representing the Integrated Assessment of Climate Change, Adaptation and Mitigation. Tyndall Centre for Climate Change Research. - Working Paper. 11. Tyndall Centre for Climate Change Research Cambridge.

Black, R. (1998) Refu gees, Environment and Development. Longman, London.

Brauch (2005) 'Threats', 'Challenges', 'Vulnerabilities' and 'Risks' of Environmental and Human Security. Publication Series of UNU-EHS No.1. United Nations University, Bonn.

Castles, S.- Miller, M.J. (1998) The Age of Migration: International Population Movements in the Modern World. Macmillan, London.

Castles, S. (2001) Environmental change and forced migration: making sense of the debate. New Issues in Refugee Research. Working Paper. No. 70. Refugees Studies Centre University of Oxford, Evaluation and Policy Analysis Unit, Oxford.

El-Hinnawi, E. (1985) Environmental Refugees. Nairobi United Nations Environment Programme, Nairobi.

Gasana, J. (2000) Natural Resource Scarcity and Violence in Rwanda. A paper presented at the IUCN World Conservation Congress, 4-1 $1^{\text {th }}$ October, 2000, Jordan.

Goldstone, J.A. (2001) Demography, Environment and Security: An Overview. - Weiner, M.-Russell, S.S. (eds.) Demography and National Security. Berghahn, New York - Oxford. 38-61. o.

Greenwood M.J. (1992) The macro determinants of international migration: A survey, Conference "Mass Migration in Europe: Implications in East and West". IAS-IIASA-IF, Vienna. 
Hárs Á. (1992) A nemzetközi migráció néhány problémájáról - Szakirodalmi áttekintés. - Szociológiai Szemle. 2. 123-137. o.

Hauge, W.-Ellingsen, T. (1998) Beyond Environmental Scarcity: Causal Pathways to Conflict. - Journal of Peace Research. 35. 299-317. o.

Homer-Dixon, T. (2004) Környezet, szükösség, eröszak. Typotex, Budapest.

IOM (2007) Discussion note to the 94th Session: Migration and the Environment. International Organisation for Migration. International Office of Migrations, MC/INF/288. http://www.iom.int/jahia/Jahia/activities/by-theme/migration-climate-change-environmentaldegradation/definitional-issues_Letöltés ideje: 2010. január 15.

Kavanagh, B.-Lonergan, S. (1992) Environmental Degradation, Population Displacement and Global Security: An Overview of the Issues, CSRD report No.1. The University of Victoria Centre for Sustainable Development, Victoria BC.

Künçek, O. (1998) Transboundary population movements: Refugees, environment and politics. - The Turkish Yearbook of International Relations. No. XXVIII. Ankara University, Ankara. 75-103. o.

Lee E. (1966) A theory of migration. - Demography. 1. 45-57. o.

Lee, S. (1994) Environmental Change, Refugees and Conflict in the Third World: A Framework for Inquiry Applied to Case Studies of Sudan and Bangladesh. University of Maryland at College Park, Maryland.

Lind, J. (2001) Project Background. In Ecological Sources of Conflicts in Sub-Saharan Africa. A Policy Research, Information Dissemination and Capacity Building Project. Background Documents. Unpublished document for ACTs, Nairobi.

Lonergan, S. (1998) The Role of Environmental Degradation in Population Displacement. Global Environmental Change and Security Project Report. - Research Report. 1. University of Victoria, Canada. http://www.gechs.org/rr1/appendices.pdf_Letöltés ideje: 2010. január 15.

Massey, D.S.-Arango, J.-Hugo, G.-Kouaouci, A.-Pellegrino, A.-Taylor, J.E. (1993) Theories of international migration: a review and appraisal. - Population and Development Review. 3. 431-466. o.

Myers, N.-Kent, J. (1995) Environmental exodus: an emergent crisis in the global arena. The Climate Institute, Washington DC.

Myers, N. (1994) Environmental refugees: a crisis in the making. - People \& the Planet. 4. www.oneworld.org/patp/pp eco refugees.html Letöltés ideje: 2010 . január 15.

Ravenstein, E.G. (1885) The Laws of Migration. - Journal of the Royal Statistical Society. June. 167-227. o.

Roson, R. (2003) Modelling The Economic Impact Of Climate Change, Ecological and Environmental Economics Programme. ICTP, University of Venice Fondazione Eni Enrico Mattei, Venice. http://www.ictp.trieste.it/ eee/files/WP9 - Roson.pdf Letöltés ideje: 2010. január 15.

Schubert, R.-Schellnhuber, H.J.-Buchmann, N.-Epiney, A.-Grießhammer, R.-Kulessa, M.-Messner, D.-Rahmstorf, S.-Schmid, J. (2008) World in Transition-Climate Change as a Security Risk, German Advisory Council on Global Change. WBGU, Earthscan, London.

Schwartz, D.M. (2002) "The Environment and Violent Conflict". - Timmerman, P. (ed.) Social and Economic Dimensions of Global Environmental Change. John Wiley, Chichester. 137-149. o.

Suhrke, A. (1993) Pressure Points Environmental Degradation, Migration and Conflict. Paper presented at the "Environmental Change, Population Displacement, and Acute Conflict" workshop held at the Institute for Research on Public Policy in Ottawa in June 1991, University Toronto and the American Academy of Arts and Sciences, Cambridge, Massachusetts.

Worldwatch Institute (2005) A világ helyzete 2005 - újragondolt biztonság. Worldwatch Institute, Washington.

Zlotnik H. (1998) The theories of international migration. Paper presented: at the Conference on international migration: Challenges for European populations. 25-27 June, Bari. 


\section{EXPLAINING ENVIRONMENTAL MIGRATION}

\section{ANDRÁS VÁG}

The study deals with environmental migration, a new form of territorial mobility. The methodological approach of the paper is basically theoretical. It summarizes the state-ofthe-art, presents the starting points of the explanations, and finally drafts a general environmental migration model. 